\title{
Analisis peraturan perkawinan beda agama di berbagai negara sebagai perlindungan hukum untuk membentuk keluarga
}

\author{
Kadek Wiwik Indrayanti ${ }^{1}$, Enny Ristanty ${ }^{2}$
}

${ }^{1}$ Kadek Wiwik Indrayanti; Fakultas Hukum Universitas Merdeka Malang; Jl. Terusan Raya Dieng No. 6264; Malang; 65146; Jawa Timur; Indonesia.

${ }^{2}$ Enny Ristanty; Fakultas Hukum Universitas Merdeka Malang; Jl. Terusan Raya Dieng No. 62-64; Malang; 65146; Jawa Timur; Indonesia.

ARTICLEINFO

Article history:

Received 2019-08-13

Received in revised form

2019-10-14

Accepted 2019-12-01

Kata kunci:

Perkawinan Beda Agama;

Perbandingan Norma; Hak

Membentuk Keluarga.

Keywords:

Interfaith Marriage; Comparison

of Norms; Right to Form a family.

DOI: https://doi.org/10.26905/

idjch.v11i1.4046.

How to cite item:

Indrayanti, KW \& Enny Ristanty. (2020). Analisis peraturan perkawinan beda agama di berbagai negara sebagai perlindungan hukum untuk membentuk keluarga. Jurnal Cakrawala Hukum, 11(1), 71-81. doi:10.26905/ idjch.v11i1.4046.

Corresponding Author:

* Kadek Wiwik Indrayanti.

E-mail address: astinaagra@yahoo.com

\section{Abstrak}

Keabsahan perkawinan beda agama (interfaith marriage) untuk warga negara Indonesia tidak diatur didalam ketentuan Undang-Undang Nomor 1 Tahun 1974 sebagai mana telah diubah dengan Undang Undang No 16 Tahun 2019 tentang perkawinanan, sementara fakta warga negara yang melakukan perkawinan beda agama semakin meningkat. Kajian perbandingan peraturan perkawinan di beberapa negara bertujuan untuk mendapatkan pengetahuan dan pemahaman yang holistik tentang peraturan-peraturan yang mengatur perkawinan, khususnya persamaan dan perbedaan perkawinan beda agama. Sehingga kedepan dapat dipakai sebagai masukan dalam mengatur peraturan perkawinan beda agama di Indonesia. Metode penelitian yang digunakan untuk menganalisis kajian ini adalah penelitian hukum normatifkarena menggunakan pendekatan perbandingan hukum di beberapa negara. Hasilnya menunjukkan bahwa keabsahan perkawinan di beberapa negara seperti USA, Australia, Singapore dan Belanda dilakukan melalui pencatatan. Hampir semua negara yang dijadikan obyek kajian mengatur perkawinan beda agama. Sehingga perlindungan terhadap hak untuk membentuk keluarga terjamin. Turki yang memiliki persamaan dengan Indonesia mengatur perkawinaan beda agama.

\section{Abstract}

The validity of interfaith marriages for Indonesian citizens is not regulated in the provisions of Law No. 1 of 1974 as amended by Law No. 16 of 2019 concerning marriages, while the fact of citizens who engage in interfaith marriages is increasing. A comparative study of marriage regulations in several countries aims to gain holistic knowledge and understanding of the regulations governing marriages, specifically the similarities and differences in marriages of different religions. So that the future can be used as input in regulating the rules of interfaith marriages in Indonesia. The research method used to analyze this study is normative legal research because it uses a comparative approach to law in several countries. The re- 


\section{Jurnal Cakrawala Hukum, Volume 11 No. 1 April 2020}

ISSN PRINT 2356-4962 ISSN ONLINE 2598-6538

sults show that the validity of marriages in several countries such as the USA, Australia, Singapore and the Netherlands is done through registration. Almost all countries used as objects of study regulate interfaith marriages. So that the protection of the right to form a family is guaranteed. Turkey which has similarities with Indonesia regulates interfaith marriages.

\section{Latar Belakang}

Warga negara Indonesia yang hendak melakukan perkawinan beda agama sampai saat ini masih belum dapat merasakan haknya untuk membentuk keluarga karena ketentuan didalam Undang Undang Nomor 1 Tahun 1974 (untuk selanjutnya disebut UU No 1 Tahun 1974) tentang Perkawinan sebagaimana diubah dengan UndangUndang Nomor 16 Tahun 2019 tentang Perkawinan tidak mengatur keabsahan perkawinan beda agama.

Keabsahan perkawinan menurut UndangUndang No 1 Tahun 1974 apabila dilakukan menurut hukum masing-masing agama dan kepercayaan. Sementara itu, fakta jumlah warga negara Indonesia yang melakukan perkawinan beda agama semakin meningkat sejumlah 1.109 pasangan yang melakukan perkawinan antara tahun 2004-2012 dan data tersebut terus meningkat (Funaro, 2019). Begitu pula dengan penolakan permohonan penetapan perkawinan yang diajukan oleh calon pasangan beda agama didalam kasus Nomor 527/ Pdt/P/2009/PN. Bgr tertanggal 16 Juli 2009, karena hakim memberikan pertimbangan hanya didasarkan pada nilai-nilai agama salah satu pasangan yaitu Islam. Selanjutnya, Putusan No. 68/ PUU-XII/2014, tanggal 18 Juni 2015 oleh Mahkamah Konstitusi menolak Uji Materi terhadap Pasal 2 ayat (1) Undang-Undang Republik Indonesia Nomor 1 Tahun 1974 tentang Perkawinan. Dengan ditolaknya permohonan tersebut maka perkawinan beda agama tetap menyisakan suatu persoalan ketidak pastian dan rasa ketidak adilan bagi calon pasangan. Adanya beragam penafsiran di masyarakat Indonesia khususnya dikalangan aparat penegak hukum yakni hakim didalam mengartikan phrases 'sahnya perkawinan harus dilakukan menurut hukum masing-masing agama dan kepercayaannya itu," yang ditafsirkan harus satu agama.

Beberapa upaya yang dilakukan oleh warga negara untuk dapat mengesahkan perkawinanya, yang paling sering dilakukan oleh salah satu calon pasangan dengan berpindah agama. Setelah itu dalam kehidupan sehari hari pasangan menjalankan agamanya masing masing. Negara belum memberikan ruang apalagi perlindungan bagi warga negara untuk melakukan perkawinan beda agama. Sementara dewasa ini adanya fakta dan perkembangan masyarakat Indonesia yang beragam dengan tingkat pertemuan yang semakin mudah dan perkembangan tehnologi menjadi penyebab terjadinya interaksi, yang menyebabkan merka saling jatuh cinta jatuh cinta kemudian perkawinan beda agama dan kepercayaan dikalangan masyarakat.

Adanya kekosongan hukum didalam Undang Undang No. 1 Tahun 1974, sehingga salah satu upaya yang dapat dilakukan dari perspektif akedemisi adalah melakukan kajian dibidang perbandingan. Atas dasar itu maka tulisan ini bertujuan untuk menelusuri dan menganalisis makna dan keabsahan perkawinan di beberapa negara, perkembangan perkawinan beda agama dan mengidentifikasi perbedaan dan persamaannnya.

\section{Metode}

Metode penelitian hukum yang digunakan dalam penelitian ini adalah menggunakan pendekatan perbandingan hukum yaitu perbandingan peraturan perkawinan di beberapa Negara sebagai 
upaya untuk melakukan perbaikan dan perluasan terus menerus terhadap pengetahuan kita, sebagai alat bantu untuk memahami peraturan peraturan hukum serta sebagai sebuah perangkat konstruksi (Cruz, 2010).

\section{Pembahasan}

\subsection{Amerika serikat (United State of America)}

Ada beberapa hal yang mendasari suatu perkawinan di Negara Amerika Serikat yaitu mencakup (Bowman, 1996) pentingnya Lembaga Perkawinan Menganugerahkan KeuntunganKeuntungan: Menurut Pengadilan Tinggi USA, perkawinan merupakan salah satu hak sipil individu yang hakiki, sebagai dasar terhadap keberadaaan dan kelanjutannya. Hak untuk kawin merupakan hak mendasar dan bersifat pribadi yang tercantum secara implisit di dalam Amandement 14 Due Process Clause dan dinyatakan bahwa perkawinan adalah suatu kelembagaan, dalam menjaga kemurnian dan sifatnya penting, yang menjadi dasar bagi keluarga dan masyarakat, tanpa adanya perkawinan tidak akan ada peradaban.

Suatu perkawinan juga memberi bermacammacam hak, manfaat dan tanggung jawab unik terhadap lembaga perkawinan. 2) Perkawinan sebagai Perhatian sebuah Negara Bagian : perkawinan di Amerika Serikat didefinisikan oleh hukum di masing masing negara bagian. Hukum perkawinan telah terbentuk dengan baik bahwa, tidak ada hukum federal bagi hubungan hubungan yang bersifat domestik. Perkawinan merupakan hal utama bagi masing masing Negara bagian. Perkawinan menciptakan hubungan yang paling penting dalam kehidupan individu; perkawinan berhubungan dengan hal-hal terkait dengan moral dan peradaban manusia dibandingkan dengan lembaga-lembaga lainnya, yang selalu menjadi target terhadap hal yang dikontrol oleh legislatif.

Negara bagian secara eksklusif mengatur hukum keluarga karena merupakan peran mendasar dari konsep kedaerahan dalam desain Pemerintah Federal. 3) Perkawinan sebagai Hak-Hak Mendasar, Perlindungan Konstitusi: Negara Bagian memberlakukan peraturan perkawinan, karena suatu perkawinan merupakan hak yang sangat mendasar. Peraturan perkawinan menjadi subyek untuk membatasi Konstitusi dan peraturan peraturan lainnya yang secara signifikan ikut campur dalam perkawinan, merupakan hal yang sangat membatasi keruwetan. 4) Perkawinan sebagai sebuah Kontrak Publik : Negara Bagian berpandangan bahwa perkawinan merupakan hubungan kontrak antara dua orang yang menimbulkan status baru. Tidak seperti kontrak kontrak yang lain, status baru yang diciptakan oleh kontrak perkawinan tidak bisa diberhentikan oleh keinginan kedua belah pihak tetapi hanya oleh hukum Negara Bagian. Hal itu yang menyebabkan Negara Bagian menjadi pihak ketiga dalam setiap perkawinan. 5) Penghormatan dan Keyakinan Penuh dan Penghargaan: Hukum perkawinan bervariasi di masing -masing negara bagian, negara harus mengatur dengan menentukan wilayah perkawinan masuk dalam wilayah asing, menjamin para pihak kepastian dan dapat diprediksi. Untuk dapat melakukan itu negara bagian harus mengukur kebijakan dari forum dan negara bagian yang lainnya, hubungan negara terhadap para pihak yang terlibat dan menjustifikasi harapan-harapan para pihak.

Perkawinan beda agama yang terjadi di masyarakat Amerka Serikat mencerminkan interaksi di masyarakat yang terbuka merupakan suatu kekuatan perubahan sosial dibidang struktur dan norma. Seberapa besar perkawinan beda agama dimungkinkan dan derajad penerimaan masyarakat serta penerimaaan institusi agama terhadap calon perkawinan beda agama menunjukkan peningkatan perubahan terjadi. Hampir 45 persen perkawinan di USA adalah perkawinan beda keyakinan.

Perkawinan beda agama merupakan simbol dari toleransi dalam masyarakat. Data statistik 


\section{Jurnal Cakrawala Hukum, Volume 11 No. 1 April 2020}

ISSN PRINT 2356-4962 ISSN ONLINE 2598-6538

menunjukkan bahwa sebanyak 20 persen pasangan perkawinan beda agama sebelum tahun 1960 dan hingga sekarang sudah mencapai 45 persen. Menurut hasil survey yang dilakukan terhadap 2450 orang: Jewis melakukan kawin beda agama paling banyak kemudian diikuti oleh Muslim dan Mormon.

Perkembangan toleransi beragama di masyarakat Amerika. Hampir 50 persen perkawinan Jewis beda agama, menyusul Muslim 40 persen dan Mormon 34 persen serta Hindu sekitar 10 persen (Interfaith Marriages, 2019). Menurut Naomi Shaefer Riley dalam bukunya yang berjudul Tiil Faith DO Us Part Tahun 2003 bahwa dampak perkawinan beda agama mengubah Amerika yang menyatakan bahwa 42 persen perkawinan adalah perkawinan beda agama. Perkawinan beda agama semakin umum disetiap daerah apapun level pendidikan dan pendapatan calon pasangan. Fenomena perkawinan beda agama di USA: anggota agama minoritas sepertinya meningkat melakukan perkawinan dengan orang yang dari luar agama dan tradisinya jika dibandingkan dengan kelompok mayoritas, 18 persen katolik kawin dengan non Katolik dan perkembangan ini meningkat mencapai 51 persen. Fenomena ini terjadi kemungkinan pada mereka yang tinggal di daerah. Awal tahun 1970 sebanyak 7 persen perkawinan Amerika Jewish memilih pasangan yang bukan Jewish dan pada tahun 1990 jumlahnya meningkat. Sementara semua perkawinan yang melibatkan Jewis Amerika antara tahun 1985-1990 mencapai 52 persen.

Pertimbangan-pertimbangan khusus pada perkawinan beda agama berupa tantangan dan manfaat bagi calon pasangan diungkapkan oleh pasangan kawin beda agama di Amerika Serikat tentang nilai-nilai. Calon pasangan yang melakukan perkawinnan beda agama mengatakan tidaklah melihat pada agama pasangannnya, yang dilihat orangnya (Brandongille, 2019).

Beberapa buku telah mengungkapkan bahwa perkawinan beda agama sebagai suatu tantangan, berisiko, menakutkan dan buruk. Namun Erika B. Seamon membawa perspektif baru tentang perkawinan beda agama dalam bukunya Interfaith Marriage in America: Past and Future. Orang Kristen telah melakukan perkawinan beda agama dengan orang diluar Kristen di seluruh dunia sejak berabad abad. Perkawinan beda agama merupakan tantangan baik secara internal maupun eksternal. Tantangan internal yang paling utama disebabkan perbedaan pemahaman secara alamiah dari perkawinan itu sendiri.

\subsection{Australia}

Pemerintah di wilayah Australia memberlakukan hukum perkawinan sejak masa penundukan bangsa Eropa. Hukum perkawinan pertama kali diberlakukan oleh penjajah Inggris yang merupakan warisan tradisi common law. Dalam beberapa waktu perkawinan terbukti dibatasi kepada calon pasangan dengan memperlihatkan karakter yang baik, tidak menunjukkan kesederhanaan atau industrionus merupakan yang tidak boleh kawin. Tahun 1901-1961 masing- masing negara bagian bertanggung jawab mengatur perkawinan dan negara bagian memiliki hukum perkawinannya masing-masing. Seperti yang diugkapkan oleh Garfield Barwick yang menjadi Hakim Mahkamah Agung menulis di tahun 1962 bahwa pada saat ini ada sembilan sistem perkawinan yang terpisah, walau memiliki beberapa persamaan, memperlihatkan keberagaman dalam prinsip dan detailnya (Barwick, 1961).

Menurut hukum, seseorang dapat kawin dan berubah dari satu negara bagian dengan yang lainnya. Sebagai contoh usia kawin, untuk laki-laki 14 tahun dan 12 tahun untuk perempuan. Pada tahun 1942 Negara Bagian Tasmania menaikkan batas usia kawin 18 untuk laki-laki dan 16 untuk perempuan. Contoh lain adanya variasi terkait dengan suku asli aborigin yang diatur dengan siapa mereka boleh atau tidak boleh kawin. Di negara 
bagian Queensland menurut the Aboriginals Protection and Restriction of the Sale of Opium Act 1897, melarang perempuan suku asli kawin dengan orang dari luar sukunya tanpa mendapat izin dari pelindung suku aborigin. Di negara bagian utara yang diatur dengan hukum common law dimana Aboriginal Ordinance 1918 membatasi perkawinan antara perempuan suku aborigin dengan laki-laki diluar sukunya. Kalaupun ada, perkawinan harus ada izin secara resmi.

Parlemen Australia Setelah tahun 1961, mengatur perkawinan dengan mengeluarkan Marriage Act 1961 mengatur perkawinan secara sama diseluruh negara. Marriage Act 1961 tidak mencantumkan pengertian perkawinan, dan pengertian perkawinan didasarkan pada sistem common law. Senator John Grey Gorton memberikan argumen pada saat itu sebagai berikut: "mengapa perkawinan tidak diberikan definisi sebelumnya, karena sulit untuk melakukannya. Perkawinan tentu saja dapat berarti bermacam-macam. Contohnya dapat diartikan seremonial keagamaan, seremonial sipil dan sebagai sebuah bentuk hidup bersama. Ada beragam arti yang melekat dalam kata perkawinan, yang menimbulkan adanya perbedaan antara satu dengan yang lainnya."

Parlemen Australia pada tahun 2004 mengundangkan the Marriage Amandement 2004, yang diperkenalkan oleh Attorney General Mr Philip Ruddock dalam Sub seksi 5 (1) Marriage Act tercantum (Barwick, 1961), marriage means the unian of a man and a women to the exslusion of all others, voluntarily entered into for life (perkawinan berarti penyatuan seorang laki-laki dan seorang perempuan yang terpisah dari lainnya, secara sukarela memasuki kehidupan untuk selamanya).

Fakta masyarakat Australia melakukan hubungan tinggal bersama seperti layaknya kehidupan perkawinan tanpa memformalkan hubungan lewat ritual perkawinan. Hanya menurut ketentuan The Family Law Act 1975 definisi hubungan hidup bersama dengan syarta-syarat yaitu: (a) kedua orang tidak dalam hubungan pernikahan secara formal satu sama lain, (b) dua orang tidak dalam hubungan keluarga dan 3) dua orang memiliki hubungan sebagai sepasang suami istri hidup bersama berdasarkan hubungan pribadi.

Fakta perkawinan beda agama di Australia secara keseluruhan meningkat. Seperti diketahui Australia merupakan salah satu negara yang multikultur di dunia. Suku Asli Aborigin dan orang-orang yang berasal dari suku yang beragam menjadikan lingkungan yang kaya dengan budaya melalui bahasa, agama, seni, dan beragama kepercayaan dan beragama kegiatan. Secara keseluruhan antara tahun 1974-1998, persentase perkawinan campuran telah menunjukkan peningkatan setiap tahunnya. Pada tahun 1974 sebanyak 39 persen perkawinan yang tercatat adalah perkawinan campur dan sampai tahun 1998 telah meningkat menjadi 52 persen.

\subsection{Singapore}

Hukum perkawinan di Singapore diatur di dalam dua Undang-Undang yakni (1) Hukum Perkawinan Islam (1966) yang diatur dalam the Administration of Muslim Law (AMLA) dan (2) the Women Charter. Pencatatan perkawinan bagi Muslim dilakukan oleh Pencatatan Perkawinan Muslim (the Registry of Muslim Marriages/ROMM), sedangkan Pencatan Sipil diatur dalam the Women Charter (Matrimonial Law of Singapore, 2016). Perkawinan sipil untuk pasangan dimana salah satunya atau dua- duanya Non Muslim, dan poligami dilarang.

Pengaturan tersebut tidak jauh berbeda dengan Malaysia sejak adanya fatwa Committe National Council on Islamic Affairs sejak tanggal 14 Juli 1977 memutuskan seorang laki-laki Muslim mengawini perempuan dari kelompok ahl al-kitab dihalalkan, tetapi perempuan Jewis dan Kristianiti yang tidak kategori sebagai ahl al-kitab dilarang dikawini. Malaysia memiliki dua sistem hukum 


\section{Jurnal Cakrawala Hukum, Volume 11 No. 1 April 2020}

ISSN PRINT 2356-4962 ISSN ONLINE 2598-6538

perkawinan yaitu perkawinan Muslim diatur oleh Islamic Family Law Act sedangkan bagi non muslim diatur oleh Law reform (Marriage and Divorce Act 1976) (Islam).

Proses perkawinan bagi masyarakat yang beragama Islam diatur sesuai dengan hukum Islam sedangkan pada perkawinan sipil para pihak cukup datang ke kantor Pencatatan Perkawinan (the Registry of Marriage (ROM) untuk mendaftarkan tanggal perkawinan dan dapat dilakukan secara online. Kemudian ada waktu sekitar 30 hari (minimum 21 hari). Calon pasangan membawa surat izin yang diperoleh dari pemuka agama, hakim, pemuka masyarakat.

Singapore mengatur beberapa jenis perkawinan selain perkawinan pada umumnya yaitu; perkawinan campuran (interfaith marriages), perkawinan sejenis (same- sex marriages) dan perkawinan antar angkatan (Marriages among Armed Forces). Perkawinan sejenis tidak diijinkan di Singapore, namun dibawah perkawinan sipil, kategori jenis kelamin seorang hanya yang tertera dalam kartu identitas. Jika seseorang memiliki transgender maka harus mengawini pasangan yang berasal dari jenis keimanan yang berbeda. Namun sebaliknya, dalam perkawinan Muslim tidak diijinkan walau orang tersebut telah melalui proses ganti kelamin.

\subsection{Belanda}

Hukum perkawinan di negara Belanda hanya mengenal perkawinan Sipil yang dilakukan oleh pencatat perkawinan (ambtenear van de burgerlijke stand) .Sesudah perkawinan sipil dilakukan, perkawinan dapat dilangsungkan dalam ritual agama. Umumnya ritual perkawinan di Belanda berlaku sah di negara lain. Konsulat Jenderal tidak memiliki otoritas mengesahkan perkawinan, menjadi saksi didepan hukum tentang kemampuan hukum seseorang untuk kawin, tidak juga membuat sertifikat perkawinan.

Pemerintah lokal hanya melakukan perkawinan jika salah satu dari calon mempelai meru- pakan penduduk sah Nederland. Departemen Imigrasi Belanda tidak memberikan jaminan status semata-mata untuk melakukan perkawinan. Kantor Penduduk atau City Hall (Stadhuis, Afdeling Huwelijkszaken) di Kotamadya, tempat perkawinan dilaksanakan akan memberikan informasi terkait dengan tata cara yang harus diikuti warga negara Belanda yang berumur dibawah 18 tahun, harus mendapatkan izin orang tua dan undang-undang kerajaan, hanya menjamin dalam situasi tertentu. Kemudian dampak dari perkawinan di Nederland terhadap kewarganegaraan tidak otomatis menjadi warga negara Belanda terhadap pengajuan seseorang (Marriage Law Netherlands, 2016).

Perkawinan sesama jenis (same-sex marriage) atau dalam bahasa Belanda Huwelijk tussen personen van gelijk geslacht dilegalkan sejak 1 April 2001, dan Nederlands merupakan negara yang pertama mengesahkan perkawinan sesama jenis. Pasal pokok di dalam peraturan mengubah Pasal 1: 30 didalam hukum perkawinan yang dibaca sebagai berikut: Sebuah perkawinan dapat dimasuki kedalam oleh dua orang yang bertentangan atau sama jenis (Een huwelijk kan worden dangegan door twee personen van verschhhillend of van gelijk geslacht).

Hukum di Belanda mensyaratkan pasangan harus memilki kewarganegaraan Belanda atau berdomisili di Nederlands. Hukum ini hanya berlaku di wilayah Eropa yang merupakan kekuasaan Belanda dan Pulau Karibia dari Boanire, St Eusstatius dan Saba, tetapi tidak berlaku terhadap negara yang konstituen dari kerajaan Nederlands.

Satu perbedaan antara perkawinan sesama jenis dan perkawinan pada umumnya adalah pada perkawinan sesama jenis, asal usul kedua pasangan tidak secara otomatis, dalam arti ibu secara hukum dari seorang anak adalah ibu biologinya (Pasal 1: 198 dari Civil Law) dan ayahnya (secara prinsip) laki-laki yang dikawini ketika anak itu lahir. Syarat lainnya seorang ayah harus seorang laki-laki (Pasal 1-199) dan pasangan lainnya mungkin menjadi ibu secara hukum hanya lewat adopsi. 


\section{Tabel 1. Norma Perkawinan dan Perkawinan Beda Agama di Berbagai Negara}

\begin{tabular}{|c|c|c|c|c|c|c|}
\hline & USA & Singapore & Australia & Belanda & Indonesia & Turki \\
\hline$>$ & $\begin{array}{l}\text { Perkawinan di } \\
\text { Negara Amerika } \\
\text { Serikat } \\
\text { mencakup } \\
\text { beberapa hal: } \\
\text { 1. Pentinganya } \\
\text { Lembaga } \\
\text { Perkawinan, } \\
\text { Menganugrah- } \\
\text { kan Keuntungan- } \\
\text { Keuntungan } \\
\text { 2. Perkawinan } \\
\text { sebagai Perhatian } \\
\text { sebuah Negara } \\
\text { Bagian } \\
\text { 3. Perkawinan } \\
\text { sebagai Hak-Hak } \\
\text { Mendasar, } \\
\text { Perlindungan } \\
\text { Konstitusi } \\
\text { 4. Perkawinan } \\
\text { sebagai sebuah } \\
\text { Kontrak Publik } \\
\text { 5. Penghormatan } \\
\text { Dan Keyakinan } \\
\text { Penuh dan } \\
\text { Penghormatan. } \\
\text { Sahnya } \\
\text { perkawinan } \\
\text { menurut hukum } \\
\text { negara yaitu } \\
\text { hanya } \\
\text { menyangkut } \\
\text { aspek } \\
\text { pencatatan. }\end{array}$ & $\begin{array}{l}\text { Ada dua } \\
\text { (2) macam } \\
\text { hukum } \\
\text { perkawin } \\
\text { an : } \\
\text { 1. Hukum } \\
\text { perkawina } \\
\text { n Islam (the } \\
\text { Admintratio } \\
\text { n of Muslim } \\
\text { Law } \\
\text { /AMLA) } \\
\text { 2. The Women } \\
\text { Charter. } \\
\text { Ada } 3 \\
\text { jenis } \\
\text { perkawin } \\
\text { an } \\
\text { 1. perkawinan } \\
\text { campuran } \\
\text { 2. perkawinan } \\
\text { sesama jenis } \\
\text { 3. perkawinan } \\
\text { antar angkatan } \\
\text { (Marriages } \\
\text { among Armed } \\
\text { Forces) } \\
\text { Perkawin } \\
\text { an } \\
\text { campuran } \\
\text { termasuk } \\
\text { perkawin } \\
\text { an beda } \\
\text { agama }\end{array}$ & $\begin{array}{l}\text { Dari tahun 1901-1961 } \\
\text { masing masing negara } \\
\text { bagian bertanggung jawab } \\
\text { mengatur perkawinan } \\
\text { yang akhirnya masing } \\
\text { masing negara bagian } \\
\text { memiliki hukum } \\
\text { perkawinannya masing- } \\
\text { masing. ada sembilan } \\
\text { sistem perkawinan yang } \\
\text { terpisah, walau memiliki } \\
\text { beberapa persamaan, } \\
\text { memperlihatkan } \\
\text { keberagaman dalam } \\
\text { prinsip dan detailnya } \\
\\
\text { Hukum perkawinan } \\
\text { diatur dalam Marriage Act } \\
\text { 1961 mengatur } \\
\text { perkawinan secara sama } \\
\text { diseluruh negara. } \\
\text { Didalam Marriage Act } \\
\text { 1961 tidak mencantumkan } \\
\text { pengertian perkawinan, } \\
\text { dan pengertian } \\
\text { perkawinan didasarkan } \\
\text { pada sistem common law. } \\
\text { The Family Law Act } 1975 \\
\text { definisi hubungan hidup } \\
\text { bersama adalah dimana: } \\
\text { a. Kedua orang tidak } \\
\quad \text { dalam hubungan } \\
\text { pernikahan secara } \\
\text { formal satu sama lain } \\
\text { b. Dua orang tidak } \\
\text { dalam hubungan } \\
\text { keluarga } \\
\text { c. dua orang memiliki } \\
\text { hubungan sebagai } \\
\text { sepasang suami istri } \\
\text { hidup bersama } \\
\quad \text { berdasarkan } \\
\text { hubungan pribadi. }\end{array}$ & $\begin{array}{l}\text { Dukum di negara } \\
\text { Belanda hanya } \\
\text { mengenal } \\
\text { perkawinan Sipil } \\
\text { yang dilakukan } \\
\text { oleh pencatat } \\
\text { perkawinan } \\
\text { (ambtenear van de } \\
\text { burgerlijke stand). } \\
\text { Sesudah } \\
\text { perkawinan sipil } \\
\text { dilakukan, } \\
\text { perkawinan } \\
\text { mungkin bisa } \\
\text { dilangsungkan } \\
\text { dalam ritual } \\
\text { agama. } \\
\text { Perkawinan } \\
\text { sesama jenis } \\
\text { (same-sex marriage) } \\
\text { atau dalam bahasa } \\
\text { Belanda huwelijk } \\
\text { tussen personen van } \\
\text { gelijk geslacht telah } \\
\text { dilegalkan sejak 1 } \\
\text { April 2001. }\end{array}$ & $\begin{array}{l}\text { Untuk WNI } \\
\text { perkawinan } \\
\text { diatur didalam } \\
\text { Undang- } \\
\text { Undang Nomor } \\
1 \text { Tahun } 1974 \\
\text { tentang } \\
\text { Perkawinan. } \\
\text { Pasal } 2 \\
\text { 1. mengatur } \\
\text { tentang } \\
\text { keabsahan } \\
\text { perkawinan } \\
\text { yang harus } \\
\text { dilakukan } \\
\text { menurut hukum } \\
\text { masing-masing } \\
\text { agama dan } \\
\text { kepercayaaan. } \\
\text { Kemudian Pasal } \\
2 \text { ayat } \\
\text { 2. menyatakan } \\
\text { bahwa setelah } \\
\text { itu perkawinan } \\
\text { harus } \\
\text { dicatatkan: Bagi } \\
\text { WNI yg } \\
\text { beragama Islam } \\
\text { di KUA dan bagi } \\
\text { selain Islam ke } \\
\text { DKCS. }\end{array}$ & $\begin{array}{l}\text { Hukum keluarga } \\
\text { diatur didalam The } \\
\text { Turkish Family Law of } \\
\text { Cyprus tahun 1951: } \\
\text { Pasal 11-23, } \\
\text { Perkawinan boleh } \\
\text { dirayakan sesuai } \\
\text { dengan agama } \\
\text { masing-masing jika } \\
\text { dikehendaki, namun } \\
\text { pendaftaran } \\
\text { dilakukan sebelum } \\
\text { perayaan } \\
\text { perkawinan. }\end{array}$ \\
\hline & $\begin{array}{l}\text { Hampir } 45 \% \text { perkawinan } \\
\text { di USA adalah } \\
\text { perkawinan beda } \\
\text { keyakinan. Perkawinan } \\
\text { beda agama merupakan } \\
\text { simbol dari toleransi } \\
\text { dalam masyarakat. Data } \\
\text { statistik menunjukkan } \\
\text { bahwa sebanyak } 20 \\
\text { persen pasangan KBA } \\
\text { sebelum tahun } 1960 \text { dan } \\
\text { sekarang sudah mencapai } \\
45 \text { persen. } \\
\text { Menurut hasil survey } \\
\text { yang dilakukan pada } \\
2450 \text { orang, Jewis } \\
\text { melakukan KBA paling } \\
\text { banyak kemudian diikuti } \\
\text { oleh Muslim dan } \\
\text { Mormon. Hal ini } \\
\text { menunjukkan } \\
\text { pekembangan toleransi } \\
\text { beragama di masyarakat } \\
\text { Amerika. Hampir } 50 \% \\
\text { perkawinan Jewis beda } \\
\text { agama, menyusul Muslim } \\
40 \% \text { dan Mormon } 34 \% \\
\text { serta Hindu sekitar } 10 \% \text {. }\end{array}$ & $\begin{array}{l}\text { Perkawinan sejenis } \\
\text { tidak dijinkan di } \\
\text { Singapore, namun } \\
\text { dibawah } \\
\text { perkawinan sipil, } \\
\text { kategori jenis } \\
\text { kelamin seorang } \\
\text { hanya yang tertera } \\
\text { dalam kartu } \\
\text { identitas. Jika } \\
\text { seseorang memiliki } \\
\text { transgender maka } \\
\text { dia harus } \\
\text { mengawini } \\
\text { pasangan yang } \\
\text { berasal dari jenis } \\
\text { keimanan yang } \\
\text { berbeda. } \\
\text { Dalam } \\
\text { perkawinan } \\
\text { Muslim tidak } \\
\text { diijinkan } \\
\text { walau orang } \\
\text { tersebut telah } \\
\text { melalui } \\
\text { proses ganti } \\
\text { kelamin. }\end{array}$ & $\begin{array}{l}\text { Secara keseluruhan antara } \\
\text { tahun 1974-1998, persentase } \\
\text { perkawinan campuran telah } \\
\text { menunjukkan peningkatan } \\
\text { setiap tahunnya. Pada tahun } \\
\text { 1974 sebanyak } 39 \text { persen } \\
\text { perkawinan yang tercatat } \\
\text { adalah perkawinan campur dan } \\
\text { sampai tahun } 1998 \text { telah } \\
\text { meningkat menjadi } 52 \text { persen }\end{array}$ & $\begin{array}{l}\text { Perkawinan beda } \\
\text { agama dapat } \\
\text { dilakukan, hanya } \\
\text { jumlahnya yang } \\
\text { belum } \\
\text { teridentifikasi }\end{array}$ & $\begin{array}{l}\text { Jumlah kasus } \\
\text { perkawinan beda } \\
\text { agama dari tahun } \\
\text { ke tahun } \\
\text { meningkat. Data } \\
\text { yang paling akhir } \\
\text { menunjukkan } \\
\text { bahwa pada tahun } \\
2011 \text { jumlah } \\
\text { perkawinan beda } \\
\text { agama mencapai } \\
229 \text { pasangan dan } \\
\text { dari tahun } 2004 \text { - } \\
2012 \text { tercatat sudah } \\
\text { mencapai } 1.109 \\
\text { pasangan. }\end{array}$ & $\begin{array}{l}\text { Turki } \\
\text { membolehkan } \\
\text { perkawinan beda } \\
\text { agama melalui } \\
\text { hukum sekuler } \\
\text { (seculer law). } \\
\text { Jumlahnya belum } \\
\text { teridentifikasi. }\end{array}$ \\
\hline
\end{tabular}

Sumber: Bahan Hukum Sekunder yang Diolah 


\section{Jurnal Cakrawala Hukum, Volume 11 No. 1 April 2020}

ISSN PRINT 2356-4962 ISSN ONLINE 2598-6538

\subsection{Turki}

Turki dipilih sebagai salah satu dari sekian negara dalam kajian perbandingan karena memiliki persamaan dengan Indonesia yakni sama-sama mayoritas penduduknya beragama Islam dan negara berbentuk republik. Hukum perkawinan disebut The Turkish Family Law of Cyprus Tahun 1951.

Turki merupakan negara yang mayoritas berpenduduk muslim sebagai negara yang pertama melakukan perubahan terhadap hukum perkawinan. Reformasi pada hukum keluarga pada awalnya disebabkan adanya proses westernisasi, sekularisasi dan modernisasi. Hukum keluarga dirubah untuk memenuhi kebutuhan praktis masyarakat. Kaum cendikiawan Turki mencoba menginterpretasikan kedua nash (al-Quran dan al-Hadist) berdasarkan makna tersirat (nilai-nilai moral atau ruh nash) yang ada pada keduanya, bukan pada makna yang tersurat. Karena makna tersebut dikontekstualisasikan berdasarkan kebutuhan masyarakat. Adapun tujuan perubahan di dalam hukum keluarga untuk terciptanya unifikasi hukum perkawinan, menciptakan kesetaraan bagi laki-laki dan perempuan, dan merespon tuntutan zaman. Contohnya adalah perubahan pada poligami, Undang-Undang Sipil Turki melarang perkawinan lebih dari satu selama perkawinan pertama masih berlangsung. Pengadilan dapat menyatakan bahwa pernikahan kedua tidak sah karena poligami dianggap sebagai perbuatan menindas kaum perempuan.

Hukum perkawinan di Turki membolehkan perkawinan dengan non- Muslim melalui hukum sekuler (seculer law). Di Turki perkawinan beda agama bukan halangan karena yang dibutuhkan aspek pencatatan Negara. Hal ini diperjelas dalam ketentuan sub Resepsi Pernikahan, yang diatur dalam Pasal 11-23 Tahun 1951 yang menyatakan bahwa perkawinan boleh dirayakan sesuai dengan agama masing- masing jika dikehendaki, namun pendaftaran dilakukan sebelum perayaan tersebut (Gotzian, 2016).
Keabsahan suatu perkawinan di negaranegara baik yang menganut sistem common law (USA, Australia, dan Singapore) ataupun sistem civil law (Belanda) didasarkan pada perkawinan secara sipil yaitu dicatatkan. Dari keempat negara yakni USA, Belanda, Australia, serta Singapore hanya Singapore,memberlakukan 2 (dua) hukum perkawinan yakni: (1) Hukum perkawinan Islam (the Admintration of Muslim Law) dan (2) the Women Charter. Negara-negara tersebut memandang suatu perkawinan sebagai hubungan keperdataan, sebagai sebuah kontrak.

Perbedaan peraturan perkawinan di negara negara Barat dengan Indonesia adalah: di Indonesia, sahnya suatu perkawinan melibatkan unsur agama dan kepercayaannya. Perkawinan tidak dapat dicatatkan kalau belum disahkan secara agama dan kepercayaan. Sedangkan negara-negara barat pada sampel diatas seremonial keagamaan tidak menentukan sahnya suatu perkawinan. Persamaaanya terletak pada aspek pencatatannya. Negara Turki mengatur sahnya perkawinann harus melalui proses pencatatan terlebih dahulu kemudian baru menurut seremoni agama-masing. Aturan tentang Perayaan Pernikahan dapat dilakukan menurut masing-masing agama hanya harus dilakukan proses pencatatan terlebih dahulu, yang terbalik dengan Indonesia.

Negara Indonesia mengatur sahnya suatu perkawinan apabila sudah dilakukan menurut hukum masing-masing agama dan kepercayaannya, dan setelah itu harus dicatatkan. Jadi ada dua (2) proses yang harus dilakukan oleh warga negara Indonesia agar perkawinannya sah yaitu secara agama dan kemudian harus dicatatkan (sah secara hukum negara). Aspek keagamaan tidak dapat ditawar lagi, tidak demikian halnya dengan negaranegara diatas, cukup dicatatkan sedangkan urusan ritual merupakan urusan masing-masing pihak. Singapura memberlakukan hukum bagi warga negaranya yang beragama Islam dan non Islam. Singapore menerima perkawinan beda agama. 
Begitu pula dengan Turki yang mayoritas penduduknya beragama Islam mengizinkan perkawinan beda agama.

Norma perkawinan di negara - negara yang dipakai sebagai perbandingan dengan Indonesia, terkait dengan perkawinan beda agama bahwa sahnya suatu perkawinan didasarkan pada aspek pencatatan. Aspek ritual keagamaan diserahkan kepada para pihak karena negara atau pemerintah tidak ikut campur mengurus aspek agama dan keyakinan karena beranggapan aspek ritual keagamaan sifatnya pribadi (privat), negara hanya mengatur kehidupan masyarakat di ruang publik. Filosofi yang mendasarinya bahwa agama merupakan masalah yang sifatnya pribadi dan prinsip tersebut dilindungi oleh konstitusinya.

Dengan demikian, untuk mengatur perkawinan beda agama di Indonesia maka perlu dipikirkan pola-pola pertukaran (mechanism interchange) yang diterapkan di berbagai negara dapat diambil sebagian yakni aspek pencatatannya. Model yang diterapkan oleh Turki dapat dipakai sebagai ide untuk memberikan perlindungan bagi warga negara yang melakukan perkawinan beda agama dalam hal pencatatannya. Jika tidak dicatatkan akan berdampak pada status dan kedudukan suami istri dan anak.

Pengaturan sahnya perkawinan warga negara Indonesia berdasarkan Pasal 2 ayat (1) dan ayat (2), sehingga untuk hal-hal yang berkaitan dengan proses ritual keagamaan diserahkan kepada masing-masing pihak. Kewajiban negara adalah memberikan ruang dengan bentuk pengakuan terhadap fakta perkawinan beda agama melalui wadah kedalam suatu norma sehingga dapat memberikan perlindungan berupa kepastian hukum dan rasa keadilan. Saat ini di Indonesia pengakuan perkawinan beda agama dapat dilakukan dengan mengajukan permohanan penetapan ke pengadilan (hakim) dan setelah memperoleh penetapan maka kedua calon pasangan dapat mengajukan pencatatan ke kantor Dinas Kependu- dukan. Akan tetapi kebanyakan hakim menolak memberikan penetapan perkawinan.

Dapat diterima karena para hakim dalam pertimbangannya lebih mengacu pada kepastian hukum yaitu Pasal 2 Ayat (2) UU No.1 Tahun 1974 yang mengharuskan calon mempelai agamanya sama. Sehingga apek kepastian, keadilan dan manfaat yang diperjuangkan oleh calon pasangan kawin beda agama belum dapat dirasakan. Sementara didalam ketentuan pasal 35 Undang Undang Nomor 23 Tahun 2006 sebagai mana telah diubah menjadi Undang Undang No 24 Tahun 2013 tentang Administrasi Kependudukan (Adminduk) dinyatakan dengan jelasa bahwa Catatan Sipil wajib untuk mencatatkan perkawinan yang mendapatkan penetapan pengadilan yang notabene adalah permohonan yang dilakukan oleh calon pasangan kawin beda agama.

Disamping adanya kekososngan hukum terhadap perkawinan beda agama terjadi pula kurangnya pemahaman dikalangan aparat Dinas Adminduk yang tidak berkenan mencatatkan perkawinan setelah menerima penetapan perkawinan. Penulis berpendapat bahwa urusan suatu perkawinan dikalangan masyarakat memang menurut semua agama dan kepercayaan merupakan hal yang sakral sifanya. Akan tetapi tugas negara dalam hal ini adalah memberikan perlindungan bagi seluruh warga negara terhadap hak untuk membentuk keluarga dan memeluk agama dan kepercayaan. Hak tersebut merupakan hak yang hakiki /mendasar bagi setiap manusia.

Jika selama ini yang dilakukan oleh warga negara pasangan beda agama dimana salah satu pihak pindah agama ke agama pasangannya hanya untuk memperoleh akte perkawinan. Tetapi didalam realitasnya mereka kembali menjalankan agama masing masing yang merupakan kesepakatan mereka dari awal untuk melakukan perkawinan beda agama. Urusan agama merupakan ranah pribadi (privat) sedangkan negara (pemerintah) mempunyai peran untuk mengatur ranah publik untuk 


\section{Jurnal Cakrawala Hukum, Volume 11 No. 1 April 2020}

ISSN PRINT 2356-4962 ISSN ONLINE 2598-6538

kepastian dan keadilan tidak terkecuali pada perkawinan. Mengutip ajaran sociological jurisprudence dari Roscou Pound ada yang menafsirkan sebagai "law as a tool of social enginnering", bahwa social engginnering bagi Pound kurang lebih sama dengan technologi dapat digunakan untuk mendaya hukum sebagai rekayasa sosial diefektifkan dalam proses yudicial /administrasi sejauh mana berpengaruh positif bagi masyarakat (Widodo \& Herlambang, 2015). Seperti dalam kasus permohonan penetapan perkawinan kedepan seyogyanya hakim didalam pertimbangannya merupakan hasil penelusuran hukum dari berbagai perspektif dan metode (inovasi), tidak hanya dari sudut satu pasal yang meyebabkan hukum terkadang tidak dapat menjawab perkembangan.

\section{Simpulan}

Deskripsi dalam pembahasan pengaturan perkawinan dibeberapa negara maka dapat disimpulkan sebagai berikut bahwa perkawinan di beberapa negara yakni Amerika Serikat, Australia dan Belanda serta Singapore keabsahannya dilakukan dengan proses pencatatan. Di Indonesia keabsahan perkawinan harus melalui dua proses yaitu ritual agama dan pencatatan.

Singapore, Malaysia dan Turki memiliki dua peraturan yang mengatur hukum perkawinan. Perkawinan di Singapore diatur di dalam dua Undang-Undang yakni (1) Hukum Perkawinan Islam (1966) yang diatur dalam the Administration of Muslim Law (AMLA) dan (2) the Women Charter. Turki Ada dua cara proses pernikahan yaitu nikah Imam dan nikah Resmi Sahnya perkawinan harus melalui proses pencatatan terlebih dahulu kemudian baru menurut seremoni agama-masing. Hampir semua negara mengakui adanya perkawinan beda agama dalam arti perkawinan beda agama diatur, kecuali Indonesia. Turki yang memiliki persamaan dengan Indonesia mayoritas penduduknya beragama Islam, perkawinan beda agama diatur melalui hukum sekuler. Turki memiliki dua peraturan yang mengatur hukum perkawinan.

\section{Daftar pustaka}

Bowman, Cyintia Grant. 1996. A Feminist Proposal to Bring Back Common Law Marriage.

Funaro, Patty. 2005. Legislative Guide to Marriage Law, legislative Services Agency. patty.funaro@legis.stat.

Barwick, G. The Commonwealth Mariage Act 1961. Melbourne University Law Review, Vol 3, 1961-1962. https: //www.google.co.id/ History of marriage Laws in Australia.

http: wikipedia/matrimonial law of Singapore.

http: Interfaith marriage. blogspot.co.id./2016/03/ Interfaith Marriages on rise in the United States.

http;// brandongaille.com 20 intriguing interfaith marriage statistic.

http;// gotzian-ade.blogspot.co.id/2014/ Pembaharuan Hukum Keluarga di Turki.

Indrayanti, K. (2016). Penetapan dan pencatatan perkawinan beda agama di Indonesia yang berkeadilan dan berkemanusian. Jurnal Cakrawala Hukum, 7(2), 195-205. doi:10.26905/ idjch.v7i2.1908.

Islam, Md. Zahidul. Interfaith Marriage In Islam And Present Situation. Global Journal of Politics and Law Research. Vol.2, No. 1.

Keputusan Mahkamah Konstistusi Nomor 68/PUU-XII/ 2014.

Keputusan Nomor 527/Pdt/P/2009/P.N. Bgr.

Meta, K. (2013). Pengangkatan sentana rajeg dalam perspektif hukum perkawinan adat Bali. Jurnal Cakrawala Hukum, 18(2). doi:10.26905/ idjch.v18i2.1120.

Pramasantya, O. (2017). Perjanjian perkawinan pasca putusan Mahkamah Konstitusi nomor 69/PUUXIII/2015. Jurnal Cakrawala Hukum, 8(2), 191-200. doi:10.26905/idjch.v8i2.1671. 
Analisis peraturan perkawinan beda agama di berbagai negara sebagai perlindungan hukum untuk membentuk keluarga Kadek Wiwik Indrayanti, Enny Ristanty

Peter de Cruz. 2010. Perbandingan Sistem Hukum , Common Law, Civil Law dan Socialist Law. Bandung. Nusa Media.

Putro, Widodo Dwi dan Herlambang Wiratrasman. Penelitian Hukum: Anatra Yang Normatif dan Empiris. Episterma Digest. Vol 5. 2015.
Undang -Undang Nomor 1 Tahun 1974 tentang Perkawinan.

www. Encyclopida.com. Interfaith Marriage.

www.helponline.com/article/nederlands/94/ Marriage Law- Nederlands. 